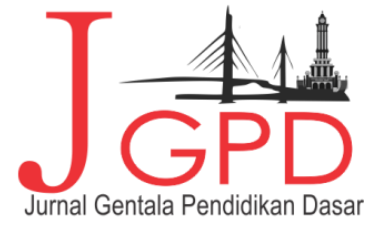

Research Article

\title{
Student Writen Conversation In The Midst Of Social Media Era
}

\section{Eko Kuntarto}

Program Studi PGSD FKIP Universitas Jambi, Jambi, Indonesia

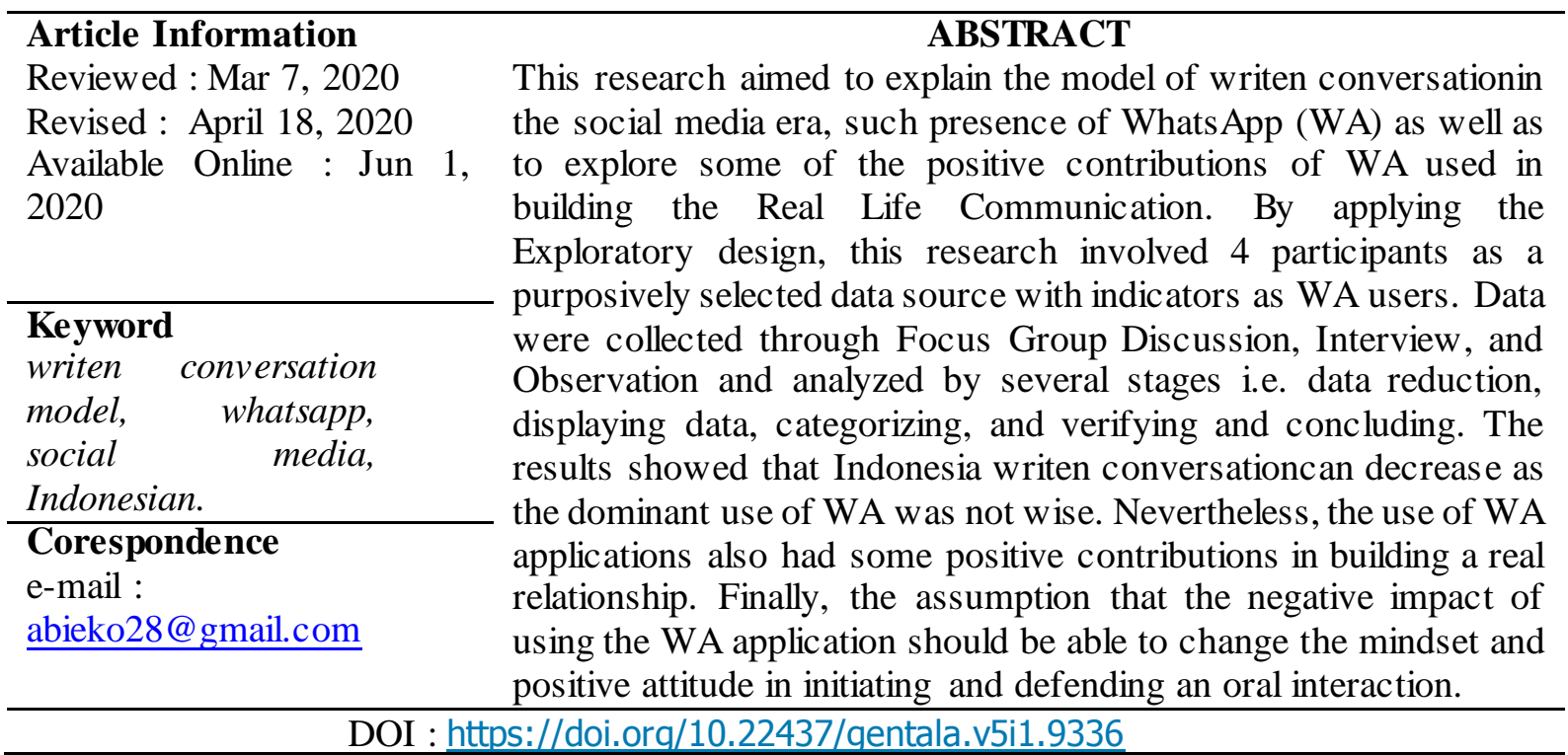

\section{INTRODUCTION}

Language consists of verbal and non-verbal symbols that are poured aplicatively in the form of oral and written text or communication. Both of these are used by humans in sharing social and cultural values when communicating. It cannot be denied that language is the only means by which humans can understand each other socially and psychologically. Arung says 'Philosophically, the language is the king of all disciplines. Without language, then it is rather difficult to describe anything to make sense of what to use it in order to get mutual understanding' (Arung, 2015). This suggests that communication will only occur through the use of language, both verbal and non-verbal.

Over time, technology is growing rapidly so that the communication media is getting closer to human life even become part of human life. The presence of communication technology is very helpful to humans in living their existence existence. However, the presence of communication technology and its types play an important role in social relationships, whenever and wherever. Ultimately, the apparent communication now can be both spoken and written communication. When viewed from the history of communication that started from the Talking era (lasting for 150,000 years), Manuscript era (lasting for 5000 years), Print era (lasting for 400 years), Audiovisual era (lasting for 140 years), to Internet era (Jones Jr , 2016), which lasted from 1990 to present, shows that 


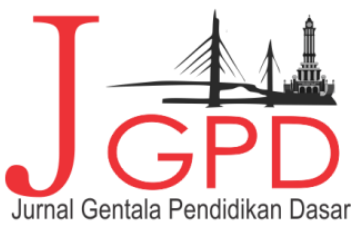

JURNAL GENTALA PENDIDIKAN DASAR Vol.5 No. I Juni 2020, Halaman 12-18

P-ISSN : 2614-7D92, E-ISSN : 2621-96II

Terbit Online Pada Laman Web : hittp://online-journal.unja.ac.id/index.php/gentala email : penyunting.jurnal.g-pgsd迎unja.ac.id

the period that really shows the nature of communication is the era of Talking era or Talking culture where speaking orally is the only means of communicating media so that social and cultural values can really shared and obtained signific antly.

One form of communications technology specifically mentioned in this research is Whats App (WA), which is a cross-platform application used for instant messaging and instant messaging that allows iPhone, BlackBerry, Android, Windows Phone and Nokia smartphone users to exchange messages texts, images, videos, and audios for free. This type of application is widely used by more than 1 billion users in 180 countries worldwide.

The presence of WA is indeed a fresh breeze for cyberspace users where they can share in a community. However, if viewed from an interactive social point of view, this kind of application has greatly underestimated the real live communication side where the face-to-face communication relationships are not so important and refer to the one to one principle. There are so many where the face-to-face communication situation is no longer a benchmark in building a wiser relationship. Often found in a face-to-face interaction, WA users no longer heed the politeness in communicating because they are only busy with their fingers on their android monitor itself. Elsewhere, the airport lounge situation that used to be alive by face-to-face communication, now feels silent and indifferent and impresses to ignore each other because each focuses solely on Android monitors with WA or similar applications.

Such conditions have also been creeping into the world of education, particularly in situations of learning, where teachers are teaching, learners also while busy with 'thumb' to compose short messages and it is most often done by women. Results of research conducted by Faulkner \& Culwin (2005) on the use of SMS in relation to gender, it can be seen that $35.6 \%$ of women tend to use SMS than men who had only been on the value of $17.3 \%$. The impact on the learning world is also evident in the results of a study conducted by Salem on the impact of BBM technology and Whats App on linguistic English learners in Kuw ait. His research shows that 'instant messaging and messaging has a negative impact on formal writing skills in the mainstream schools (Salem, 2013).' This is due to their habit of typing short messages that affect them in formal writing.

The other side of the use of mobile phones, sometimes its use is limited to the purpose of identity performances so that real and interactive communication is not possible anymore. This is in line with the results of research conducted by Gordon et al. about the use of mobile phones among students of Oman, Ukraine. His research shows that in addition to being a cultural tool, students also use it for the purpose of 'cultural meanings of personal identity,' (Gordon, Zidjaly, \& Tovares, 2017). This can certainly reduce the intensity and quantity of oral and verbal communication when mobile phone users tend to be consumptive. Different from the research conducted by Choi et al., found that the different online social networking contexts can further increase the political participation for those 


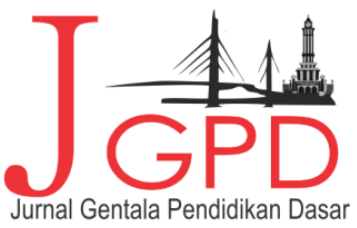

JURNAL GENTALA PENDIDIKAN DASAR Vol.5 No. I Juni 2020, Halaman 12-18

P-ISSN : 2614-7092, E-ISSN : 2621-46II

Terbit Online Pada Laman Web : hittp://online-journal.unja.ac.id/index.php/gentala email : penyunting.jurnal.g-pgsd回unja.ac.id

who tend to be involved in the posting of information or news (news externalizing). They further pointed out that it is likely that the previous researchers underestimated the influence of social netw orks because they did not take into account the individual variance of actual behaviors in social networks'(Choi, Lee, \& Metzgar, 2017). They assume that previous researchers too or less estimate the influence of social networking because previous researchers did not pay attention to the variance of individual attitudes in social networking systems. Individual attitude here certainly depends on how his mindset as a member of the language community in using social networking applications. In other words, what tendencies he will display when interacting in a language community, whether by using Computer-Mediated Communication or with the Face-to-Face talk system.

Paul and Lester say '... a great deal of attention has been described over the years by conversation analysts' (Paul, Warren, \& Lester, 2016). Here it is very clear that Conversational Analysts have clearly described how online communication is so different from Face to Face (F2F) interactions. As is known that the use of WA applications are very popular among the people in Jakarta and surrounding areas while FB and BBM tend to be used by people in Sulawesi island. This, according to the authors' observations, undoubtedly negatively impacted the F2F communication system for the authors that it constitutes one of the most human characteristics as a social being requiring writen conversationwith other humans (F2F). It can be argued that the cause of this situation is likely not by the WA application but rather to its users or perhaps even the other way around.

Previous research has provided some clear results regarding the use of Computer-Mediated Communication such as WA, Facebook, Twitter, and so on. Some results show advantages for a particular domain so that they are impressed that the use of such an application is really useful. However, there are things that have not been highlighted from previous studies so that now, I am trying to highlight certain things that for me need to be examined as a series of social phenomena that also need to be known to the public, in particular the language community. In this regard, this study aims to gain a transient view and description of the model of the main functions of writen conversation(F2F) with the presence of Computer-Mediated Communication such as WA and the impact of its usage as an online talk application to the reality of verbal interaction in the language community.

Based on the aforementioned research objectives, several problems can be formulated namely a) does writen conversationc an survive as a hallmark of the language community with the presence of closed-network like WhatsApp? b) how can a Closed-network like this make a positive contribution in building a real live communication? 


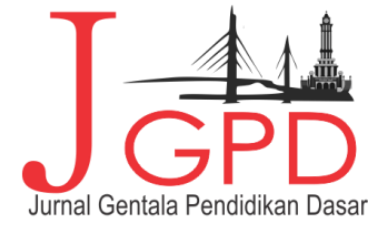

METHODOLOGY

This research applied Exploratory design with qualitative approach. Exploratory research aims to gain a deeper knowledge of an object by exploring the parts that have not been highlighted by previous researchers (Patton, 2002) so as to enable the emergence of a temporary answer (hypothesis) (Cohen, Manion, \& Morrison, 2007). The data in this study came from several participants involved in a Focus Group Discussion (FGD), interview, and observation. By that, all data in this study were collected through FGD activities and observations made on the characteristics of the research focus. FGD activities were conducted by involving 3-4 participants by discussing several topics that had been prepared and certainly related to the focus and sub-focus in this research. The results of the FGD and interview activities were transcribed to facilitate the researchers in performing the process of data analysis. The data that had been collected and then analyzed qualitatively by reducing in aiming to remove or reduce the form of data that was considered inadequate or unrelated to the research focus. Furthermore, data organized from the reduction process were included in the help table in order to display data in the form of classification. After that, the data that had been classified was then analyzed to bring up the theme which was further explored. The result of the exploration of the theme was then verified to the conclusion that was the answer to the research question that had been formulated previously.

\section{FINDINGS AND DISCUSSION}

This study aimed to reveal the model of writen conversationwithin a community with the presence of android applications such as WhatsApp (WA) that impressed supplementary of human's way of interacting with each other. Next, this study also aimed to see the positive contribution of WA use in human social interaction in establishing Real Live Communication.

\section{The Model of Writen Conversation with Closed-network Presence like What'sApp}

Every human being must have the instinct of a good relationship with each other as part of the existence of his life and at the same time as a spiritual need. An interaction involves the various elements that are also the determinants of the success of interpersonal and intergroup relationships. The elements in question are linguistic elements that include phonology, morphology, syntax, semantics, and pragmatics that can be transferred verbally and non-verbally. Next is a psychological element that involves mind, emotion, and willingness. The third element is the social and cultural elements that include patterns of community life, identity, customs, imaging. 


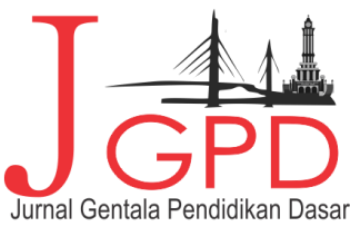

\section{JURNAL GENTALA PENDIDIKAN DASAR Vol.5 No. I Juni 202D, Halaman 12-18 \\ P-ISSN :2614-7092, E-ISSN : 2621-45니 \\ Terbit Online Pada Laman Web : hittp://online-juurnal.unja.ac.id/index.php/gentala email : penyunting.jurnal.g-pgsd回unja.ac.id}

Referring to these three elements, an writen conversation should have these three elements in order for their survival to be maintained. Its survival depends entirely on the involvement of these elements because they are strong supports in the struggle and maintenance of a good relationship.

Technological advances, particularly in information and communication systems, have led to the emergence of a memorable phenomenon that a relationship can be woven constantly in a virtual world. This certainly invites a variety of polemics that specifically focus on verbal and non-verbal interactions. Almost all interactions are done under unreal conditions and situations. However, interper sonal and intergroup interactions still exist with the use of information and communication technology. The need for technology is unavoidable but on the other hand, its presence can have a negative impact on human life specifically on patterns of oral interaction.

Based on the results of data analysis obtained through FGD, interviews, and observations, it can be said that F2F interaction will not be able to exist when the use of technology applications of WA and the like is more dominated the activities of human interaction. What's more, this situation is supported by several things, among them as follows.

a) The need for technology

b) Interest and curiosity of human beings towards something new

c) Hope for an immediate desire

d) The dominance of hedonism and meterialism

In this respect, research participants are deeply concerned about the existence of oral interactions. According to their experience and observations, writen conversationhave begun to decline since the use of WA and the like is of concern to many people for use in interacting or communicating and establishing social networks, even homes, family members have less experience and feel the impact of oral interactions.

\section{Positive Contribution of WA Applications in Establishing the Real Live Communication}

The result of data analysis shows so much negative impact of WA application usage. However, some of the positive contributions that the WA application can make in establishing a tangible relationship are visible to users who can be wise in its use. The positive contribution shown is as follows.

The result of data analysis shows so much negative impact of WA application us e. How ever, some of the positive contributions that the WA application can make in establishing a real relationship if the user can be wise in their use. The positive contribution shown are as follows. 

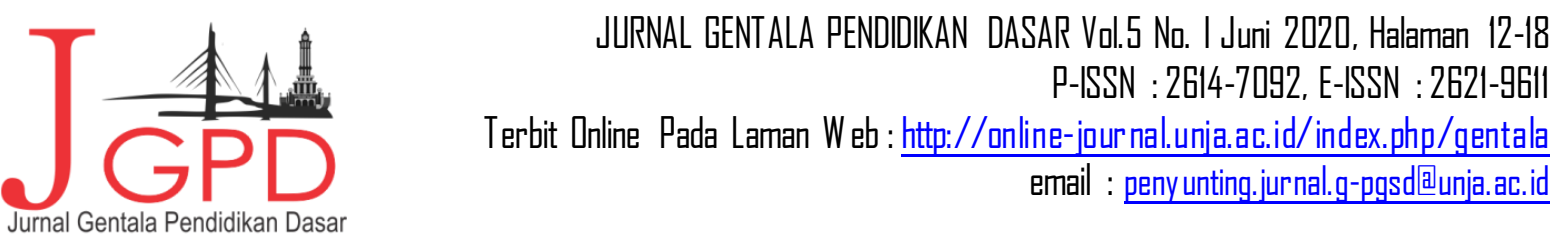

a) Facilitating access to a variety of information as needed with a relatively cheap cost and with short content.

b) Extending tentative social networks and solidarity.

c) Stimulating the initiation of iterpersonal and inter-group relationships.

d) Providing interaction services to many people at once wherever and whenever.

e) Facilitating certain tasks.

Positive things described should be the basis for building a wiser attitude toward the use of WA application and the like. Integrity and consistency in attitude is needed in addressing the use of technology such as WA application and the like. It should be understood that excessive consumer attitudes can result in a decrease in competitiveness and creativity. On the other hand, the lack of writen conversationcan lead to reduced analytical and critical power to a real phenomenon that can lead to a person's cognitive weaknesses. In oral interactions, the three previously mentioned elements are actually more noticeable and felt when compared to interactions with computerized tools or WA technology applications and the like. The thicker the three elements then the more clear and rich know ledge that is divided when interacting.

It cannot be denied that some people feel the benefits of using WA applications and the like, but the benefits of psychological relationships are temporarily ignored. Research participants gave the view that the use of WA applications and the like would unwise mislead a person's social psyche, could lead to misunderstandings and misinterpretations, diminish actual forms of expression of attention and affection, reduce sincerity in expression, and character shifts which may be more of an isolative and skeptical attitude.

Based on this and taking into consideration the model of oral interactions, researchers have instead focused on the negative impacts caused by the use of WA application and the like with the purpose of keeping and maintaining writen conversationas a basic human need in existence. If we all agree that the dominance of writen conversationis a shared need that needs to be improved then we all need to think and understand that any negative form of unwholesome use of WA application and the like can actually undermine the existence of oral interactions. In other words that one of the basic needs in life has been ignored and torn down. Wise and persistent interactions are the interactions that should be initiated orally until each individual involved in the writen conversationhas felt and experienced intimate closeness and then can think to support it with the help of technology such as WA applications and the like.

Therefore, a wise attitude in using WA application and the like is very important to consider. In addition, use that applic ation only to provide brief and practical information, never think of replacing 


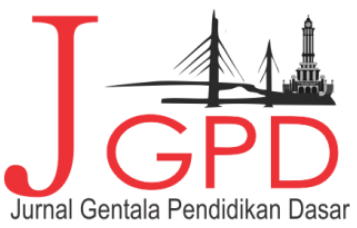

JURNAL gENTALA PENDIDIKAN DASAR Vol.5 No. I Juni 2020, Halaman 12-18

P-ISSN : 2614-7092, E-ISSN : 2621-56il

Terbit Online Pada Laman Web : http://online-juurnal.unja.ac.id/index.php/gentala email : peny unting.jurnal.g-pgsd国unja.ac.id

interactions with the use of WA application and the like, use only at the time of the vacant, the application can be used only in remote conditions and as much as possible to initiate and expect oral interaction, as well as consistency of interaction management through WA needs to be determined at the beginning so as to be more directed.

\section{CONCLUSION}

The model of Indonesian writen conversation can be worried about weakening because the use of WA application technology and the like is not wise so it takes a wise attitude in dealing with its use. Positive contributions that can be felt through the use of WA applications should not ig nore the psychologic al benefits of an writen interaction. The negative impact of unwise use of WA application can be the basis of thinking and attitude to keep and maintain verbal or writen conversation so that the balance between human creativity in inventing technology and its use is maintained.

\section{REFERENCE}

Arung, F. (2015). The Role and the Use of Indonesian Language in the Teaching and Learning English as a Foreign Language. Advances in Language and Literary Studies, 6(5), 242.doi: http://dx.doi.org/10.7575/aiac. alls.v.6n.5p.

Choi, J., Lee, J.K., \& Metzgar, E.T. (2017). Investigating Effects of Social Media News Sharing on the Relationship between Network Heterogeneity and Political Participation.Computers in Human Behavior, Vol. 7, 25-31. doi:http://dx.doi.org/10.1016/j.chb.2017.05.003.

Cohen, L., Manion, A., \& Morrison, K. (2007). Research Methods in Education-Sixth Edition. New York: Routledge

Faulkner, X. \& Culwin, F. (2005). When Fingers Do the Talking: A Study of Text Messaging. Interacting with Computers, Vol. 17, 167-185. doi:10.1016/j.intcom.2004.11.002

Gordon, C., Zidjaly, N.A., \& Tovares, A.V. (2017).Mobile Phones as Cultural Tools for Identity Construction among College Students in Oman, Ukraine, and the U.S.,Discourse, Context \& Media. doi: http//dx.doi.org/10.1016/j.dcm.2017.01.006.

Jones Jr., R.G. (2016). Communication in the Real World: An Introduction to Communication Studies. Minnesota:University of Minnesota Libraries Publishing..

Patton, M.Q. (2002). Qualitative Evaluation and Research Methods-Third Edition. California: Sage Publications, Inc.

Paulus, T., Warren, A., \& Lester, J.N. (2016). Applying Conversation Analysis Methods to Online Talk: A Literature Review. Discourse, Context and Media, Vol. 12, 1-10, doi: http://dx.doi.org/10.1016/j.dcm. 2016.04.001.

Salem, A.A.M.S. (2013). The impact of Technology (BBM and WhatsApp Applications) on English Linguistics in Kuwait. International Journal of Applied Linguistics \& English Literature,2(4), doi: http://dx.doi.org/10.7575/aiac.ijalel.v.2n.4p.64 